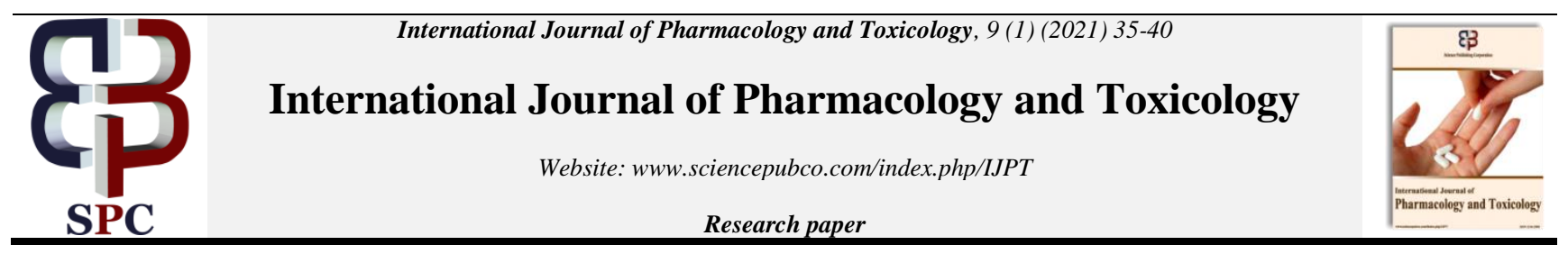

\title{
Assessment of the total aqueous stem bark extract of Sacoglottis gabonensis (Baille) Urban on the anatomo-histology of Wistar rat liver, kidneys and heart
}

\author{
Kouassi Kousso Brigitte ${ }^{1}$, Gnangoran Boua Narcisse ${ }^{1 *}$, Kouadio Yao Emile ${ }^{2}$, Koné Mama ${ }^{1}$, Yapo Angoué Paul ${ }^{1}$ \\ ${ }^{1}$ Laboratory of Physiology, Pharmacology and Pharmacopoeia, Training and Research Unit of Nature Sciences of University of \\ Nangui Abrogoua, 02 BP 801 Abidjan 02, Côte d'Ivoire \\ ${ }^{2}$ National Laboratory for Agricultural Developement Support, Central Veterinary Laboratory of Bingerville, BP 206 Bingerville, \\ Côte d'Ivoire \\ *Corresponding author E-mail: gnangorannar.sn@univ-na.ci
}

\begin{abstract}
Sacoglottis gabonensis is a medicinal plant used traditionally for the treatment of Buruli ulcer in Côte d'Ivoire. To ensure its effect over a long period of use, assessment of the total aqueous stem bark extract of S. gabonensis (ETASg) on anatomo-histology of Wistar rat liver, kidneys and heart was evaluated. ETASg was administered to Wistar rats at doses of 3.5; 35 and $350 \mathrm{mg} / \mathrm{kg} /$ day for 90 days. The liver of rats treated with ETASg at 35 and $350 \mathrm{mg} / \mathrm{kg}$ showed color and appearance changes with whitish nodules. Furthermore, histological architecture revealed micro-vesicular steatosis. In contrast, gross examination did not showed any change color and appearance of the kidneys and heart of the rats tested at all doses of ETASg compared to those of control rats. Histological sections of the kidneys and heart of rats tested at all doses of ETASg showed normal kidney and heart cells. After stopping the administration, the liver abnormalities disappeared at the end of the 120 days. This study revealed that the integrity of the liver tissue is preserved only with ETASg of $3.5 \mathrm{mg} / \mathrm{kg}$. On the other hand, it is guaranteed at all the doses studied for the renal and cardiac tissues.
\end{abstract}

Keywords: Anatomo-Histological; Heart. and Kidneys; Liver; Rats; Sacoglottis gabonensis.

\section{Introduction}

The use of herbal remedies is an integral part of African culture. According to World Health Organization (WHO), more than $80 \%$ of the African population still use medicinal plants for their primary health care (WHO, 2008). However, this use is done without precaution. It exposes patients to the risk of poisoning which sometimes proves to be fatal (Fennell et al., 2004). Several cases of severe, even fatal, intoxication due to the empirical use of concentrated decocts based on medicinal plants, have caused cases of liver damage and renal failure (Nortier et al., 1999 ; Peyrin-Biroulet et al., 2004).

In view of the above, it is necessary to carry out toxicological studies on medicinal plants used for the health care of populations. With this in mind, we have initiated research on Sacoglottis gabonensis (Baille) Urban (Humiriaceae), a medicinal plant used traditionally for the treatment of Buruli ulcer in Côte d'Ivoire. S. gabonensis is a large tree 25 meters or more in height, with dark, rough bark. It is encountered both in West Africa and in Central Africa (Aubréville, 1959). Authors found that the decoction of the stem bark of S. gabonensis is administered orally as a drink and applied locally in the treatment of Buruli ulcer (Vangah et al., 2000). Researchers showed the antimycobacterial activity on the in vitro growth of Mycobacterium ulcerans from the total aqueous extract of the stem bark of $S$. gabonensis (ETASg) (Koné et al., 2007). In addition, acute and subacute oral toxicity tests performed in mice and rats, respectively, have shown that ETASg has an LD 50 greater than $5000 \mathrm{mg} / \mathrm{kg}$ b. w. These tests also showed that it preserves the integrity of the liver, kidney and heart tissue in rats during 28 days of administration (Koné et al., 2009).

In order therefore to guarantee its safety over a long period of use and recommend it as an alternative means in the management of Buruli ulcer in Côte d'Ivoire, this work aims at elucidating the toxicity effects of ETASg on rats' liver, kidneys and heart tissues for 90 days.

\section{Materials and methods}

\subsection{Materials}




\subsubsection{Plant material}

The stem barks of S. gabonensis were harvested in November 2016, in Ingrakon, in the departement of Alépé (Côte d'Ivoire), located at about $45 \mathrm{~km}$ from the city of Abidjan. A sample was identified and kept at the herbarium of the National Floristic Center of Abidjan (Côte d'Ivoire), under the number 131.

\subsubsection{Animal material}

The experiments were conducted on albino rats of the species Rattus norvegicus strain Wistar. The rats were six to eight weeks old and weighed between 73 and 103 grams. They were bred in animal house of Physiology, Pharmacology and Pharmacopeia laboratory of the University of Nangui Abrogoua (Abidjan, Côte d'Ivoire) according to the principles for the care and use of laboratory animals of the Ethical Committee of the University (Nangui Abrogoua, Abidjan, Côte d'Ivoire). The rats were acclimated to temperature of $22 \pm 2{ }^{\circ} \mathrm{C}$ and an alternantion of 12 hours of light and 12 hours of darkness. They were fed daily with IVOGRAIN ${ }^{\circledR}$ pellets and had access to water at will in their bottles.

\subsection{Methods}

\subsubsection{Preparation of the stem barks total aqueous extract of Sacoglottis gabonensis}

The total aqueous extract of $S$. gabonensis stem barks (ETASg) was obtained according to the method described by some authors (Koné et al., 2009). The fresh stem barks of S gabonensis harvested were carefully cleaned and then dried in Laboratory for three weeks at room temperature of $25 \pm 2{ }^{\circ} \mathrm{C}$. After drying, these barks were reduced to a fine powder by means of an d'un electric grinder (Culatti, France). Four hundred grams ( $400 \mathrm{~g})$ of stem bark powder was put in $2 \mathrm{~L}$ of distilled water, and the whole was boiled at $100{ }^{\circ} \mathrm{C}$ for 30 minutes. The decoction obtained was double-filtered on hydrophilic cotton and Whatman filter paper $\mathrm{N}^{\circ} 1$. The filtrates were evaporated and oven dried at $50{ }^{\circ} \mathrm{C}$ for 48 hours. A quantity of $31 \mathrm{~g}$ of black-brown powder with a yield of $7.75 \%$ was obtained and stored in refrigerator at $7{ }^{\circ} \mathrm{C}$ until use.

\subsubsection{Experimental design}

Subchronic toxicity was based on OECD guideline 408 (OECD 1998) which consisted in administering four doses of drugs, daily, by oral route to four different groups of animals for 90 days. Eighty (80) rats were homogeneously distributed in four groups of 20 rats each. Each group consisted ten males and ten females. The dosages of ETASg administered and method described in this study were in accordance with those reported by Kouassi et al. (2018). A volume of a solution of $2 \mathrm{~mL} / 100 \mathrm{~g} \mathrm{~b}$. w. was administered to the rats orally. The control group (A) received distilled water. Groups B, C and D respectively received $3.5 ; 35$ and $350 \mathrm{mg} / \mathrm{kg} \mathrm{b}$. w. of ETASg for 90 days. The dose of $3.5 \mathrm{mg} / \mathrm{kg} \mathrm{b}$. w. was considered the therapeutic dose of the traditional practitioner. Two additional groups $\mathrm{E}$ and $\mathrm{F}$ of ten rats each of which 5 males et 5 females, were included in the control group and in group $\mathrm{D}$, in order to possibly observe the reversibility of the toxic effects 30 days after stopping the administration, or an experimental period of 120 days.

\subsubsection{Collection of tissue samples}

At the end of the 90 days of administration, all the rats treated were weighed 24 hours after the last administration. They were then kept fasted for overnight before sacrifice. Animals in each batch were anaesthetized by ether. A dissection was made and the organs such as liver, kidneys and heart were isolated. The organs were dried by blotting paper and then the tissues were kept in normal saline immediately for histopathological examination. This operation was resumed at the end of the 120 days as regards the study of the reversibility of the toxic effects

\subsubsection{Histological preparation of tissues}

Observation with the naked eye made it possible to appreciate the possible macroscopic alterations which could often indicate the nature of toxicity. It focused on appearance, color and consistency of the organs removed (Martoja and Martoja-Pierson, 1967). The liver, kidneys and heart were removed and weighed immediately using a precision balance (NEO-TECH SA, Belgique). The relative organs body weight were calculated using the formula described by (Rocquelin, 1979):

$$
\text { Relative organs body weight }(\%)=\frac{\text { Absolute organ weight }(\mathrm{g})}{\text { Animal body weight }(\mathrm{g}) \text { on the day of sacrifice }(\mathrm{g})} \times 100
$$

The microscopic test was consisted in detecting the histological anomalies. Longitudinal sections were made on the liver, kidneys and heart. They were immediately fixed in $10 \%$ formalin in order to perform histological sections stained with hematoxylin-eosin using the paraffin embedding technique as described by (Hould, 1984). This technique was carried out in three steps. The first step was to impregnate the organ parts contained in cassettes in an AXEL JOHNSON LABSYSTEM, paraffin container. The second step made thin cuts on the paraffin blocks containing the organs using a rotary microtome (SHANDON AS 325, Suisse). The last step consisted in observing the histological sections with a binocular optical microscope of the OPTIKA brand, after their staining with hematoxylin-eosin. The photos are taken using a SONY-NEX 500 brand electronic photographic camera adapted to the microscope objective.

\subsection{Statistical analysis}

The anatomo-histological results were represented as a proportion and their analysis was carried out using the G test, that is to say the parametric comparison test of k proportions. Statistical analyzes of the average relative masses were carried out using GraphPad Prism software version 5.01 for Windows (GraphPad Software Inc, San Diego, MO, Califormia/USA, 2007). They were expressed as means followed by their standard error on the means (M \pm ESM) thanks to the test of analysis of variance with two factors (ANOVA 2) with 
repeated measurement with the mixed model associated with the post-hoc test from Bonferroni. Statistical tests were considered significant for a probability level $\mathrm{p}<0.05$.

\section{Results}

\subsection{Effects of ETASg on the macroscopic appearance of the liver, kidneys and heart of wistar rats}

Anatomohistological study conducted after a period of 90 days, results did not revealed any significant $(\mathrm{p}>0.05)$ change in the relative liver, kidney and heart weights of rats' treated with $3.5 \mathrm{mg} / \mathrm{kg}, 35 \mathrm{mg} / \mathrm{kg}$ and $350 \mathrm{mg} / \mathrm{kg} \mathrm{b}$. w of the total aqueous extract of S. gabonensis stem bark compared to that of the control rats (Table 1).

\begin{tabular}{|c|c|c|c|c|c|c|c|}
\hline \multicolumn{2}{|c|}{$\begin{array}{l}\text { Macroscopic } \\
\text { Observations } \\
\text { Organs } \\
\end{array}$} & \multirow{2}{*}{$\begin{array}{l}\text { Color } \\
\mathrm{N}(100 \%)\end{array}$} & \multirow{2}{*}{$\begin{array}{l}\text { Appearance } \\
\text { SF }(100 \%)\end{array}$} & \multirow{2}{*}{$\begin{array}{l}\text { Anomaly } \\
\text { No }\end{array}$} & \multirow{2}{*}{$\begin{array}{l}\text { Body weight }(\mathrm{g}) \\
178.3 \pm 6.25\end{array}$} & \multirow{2}{*}{$\begin{array}{l}\text { organ weight }(g) \\
6.20 \pm 0.23\end{array}$} & \multirow{2}{*}{$\begin{array}{l}\text { Relative organs body weight (\%) } \\
3.49 \pm 0.08\end{array}$} \\
\hline \multirow{4}{*}{ Liver } & A (Distilled water) & & & & & & \\
\hline & $\mathrm{B}(3.5 \mathrm{mg} / \mathrm{kg})$ & $\mathrm{N}(100 \%)$ & SF $(100 \%)$ & No & $186.4 \pm 8.24$ & $6.66 \pm 0.22$ & $3.61 \pm 0.09$ \\
\hline & $\mathrm{C}(35 \mathrm{mg} / \mathrm{kg})$ & $\mathrm{B}(10 \%)$ & $\mathrm{SC}(15 \%)$ & Yes & $161.1 \pm 9.11$ & $5.61 \pm 0.18$ & $3.71 \pm 0.31$ \\
\hline & $\mathrm{D}(350 \mathrm{mg} / \mathrm{kg})$ & $\mathrm{B}(20 \%)$ & $\mathrm{SC}(35 \%)$ & Yes & $148.5 \pm 6.52$ & $5.72 \pm 0.35$ & $3.88 \pm 0.18$ \\
\hline \multirow{5}{*}{ Kidneys } & A (Distilled water) & $\mathrm{N}(100 \%)$ & SF $(100 \%)$ & No & $178.3 \pm 6.25$ & $0.94 \pm 0.07$ & $0.53 \pm 0.04$ \\
\hline & $\mathrm{B}(3.5 \mathrm{mg} / \mathrm{kg})$ & $\mathrm{N}(100 \%)$ & SF $(100 \%)$ & No & $186.4 \pm 8.24$ & $1.24 \pm 0.06$ & $0.67 \pm 0.03$ \\
\hline & $\mathrm{C}(35 \mathrm{mg} / \mathrm{kg})$ & $\mathrm{N}(100 \%)$ & SF $(100 \%)$ & No & $161.1 \pm 9.11$ & $1.00 \pm 0.05$ & $0.62 \pm 0.02$ \\
\hline & $\mathrm{D}(350 \mathrm{mg} / \mathrm{kg})$ & $\mathrm{N}(100 \%)$ & SF $(100 \%)$ & No & $148.5 \pm 6.52$ & $0.87 \pm 0.05$ & $0.59 \pm 0.03$ \\
\hline & A (Distilled water) & $\mathrm{N}(100 \%)$ & SF $(100 \%)$ & No & $178.3 \pm 6.25$ & $0.62 \pm 0.02$ & $0.35 \pm 0.01$ \\
\hline \multirow{3}{*}{ Heart } & $\mathrm{B}(3.5 \mathrm{mg} / \mathrm{kg})$ & $\mathrm{N}(100 \%)$ & SF $(100 \%)$ & No & $186.4 \pm 8.24$ & $0.72 \pm 0.03$ & $0.39 \pm 0.02$ \\
\hline & $\mathrm{C}(35 \mathrm{mg} / \mathrm{kg})$ & $\mathrm{N}(100 \%)$ & SF $(100 \%)$ & No & $161.1 \pm 9.11$ & $0,60 \pm 0.02$ & $0.38 \pm 0.02$ \\
\hline & $\mathrm{D}(350 \mathrm{mg} / \mathrm{kg})$ & $\mathrm{N}(100 \%)$ & SF $(100 \%)$ & No & $148.5 \pm 6.52$ & $0.59 \pm 0.04$ & $0.41 \pm 0.03$ \\
\hline
\end{tabular}

The values are expressed as means followed by standard error the mean $(\mathrm{M} \pm \mathrm{ESM}) ; \mathrm{n}=20$ rats ; A : Group of rats tested with distilled water; B : Group of rats tested at $3.5 \mathrm{mg} / \mathrm{kg} \mathrm{b}$. w. of ETASg ; C : Group of rats tested at $35 \mathrm{mg} / \mathrm{kg} \mathrm{b}$. w. of ETASg ; D :Group of rats tested at $350 \mathrm{mg} / \mathrm{kg}$ b. w. of ETASg ; N: Normal ; B : Blackish ; SF : Smooth and Firm to the touch; SC : Soft Consistency.

The liver of rats tested with $3.5 \mathrm{mg} / \mathrm{kg}$ b. w. of ETASg for 90 days was similar to what was observed in the control rats. Results showed light brown color and normal appearance, that is to say smooth and firm to the touch (Figs. $1 \mathrm{~A}$ and B). In contrast, liver of rats tested with $35 \mathrm{mg} / \mathrm{kg}$ b. w. of ETASg showed blackish color, soft consistency and nutmeg appearance namely granita with whitish nodules in place (Fig. $1 \mathrm{C}$ ). These nodules were also present in greater quantity on the liver of the rats tested with $350 \mathrm{mg} / \mathrm{kg} \mathrm{b.} \mathrm{w.} \mathrm{of} \mathrm{ETASg} \mathrm{(Fig.} 1 \mathrm{D}$ ). Concerning the kidneys and the heart, control rats showed light reddish color and normal appearance (Figs. $2 \mathrm{~A}_{1}$ and $\mathrm{A}_{2}$ ). Similar observations are recorded in rats tested with all doses studied of ETASg (Figs. $2 \mathrm{~B}_{1}, \mathrm{~B}_{2}, \mathrm{C}_{1}, \mathrm{C}_{2}, \mathrm{D}_{1}$ and $\mathrm{D}_{2}$ ).
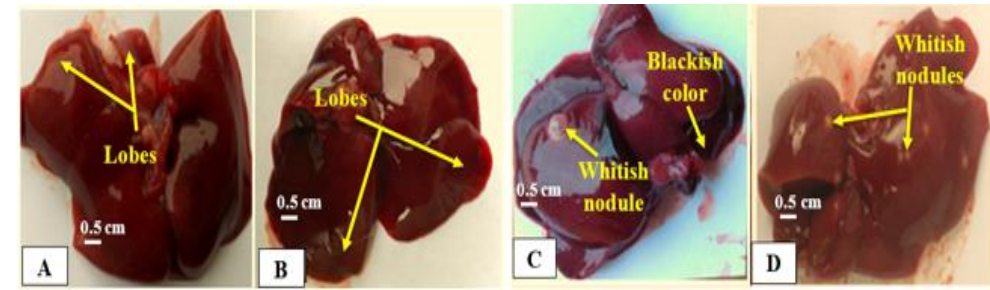

Fig. 1: Macroscopic Appearance of the Liver of Rats Tested with Etasg for 90 Days. A : Liver of Control Rat ; B : Liver of Rat Tested with 3.5 Mg/Kg B. W. ; C : Liver of Rat Tested with $35 \mathrm{Mg} / \mathrm{Kg} \mathrm{B}$. W. ; D : Liver of Rat Tested With $350 \mathrm{Mg} / \mathrm{Kg} \mathrm{B}$. W.
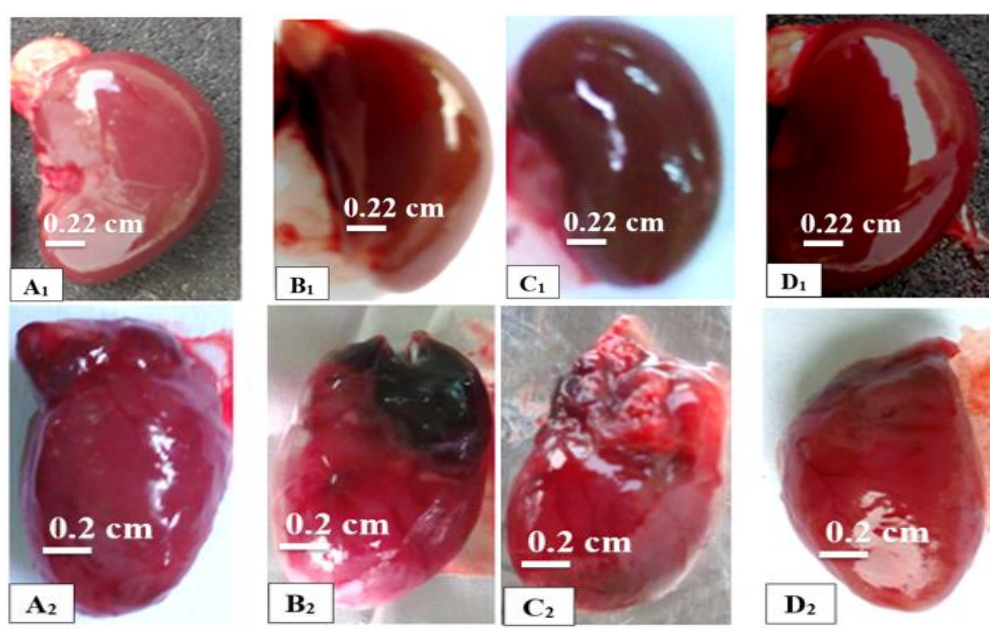

Fig. 2: Macroscopic Appearance of the Kidneys and Heart of Rats Tested with Etasg for 90 Days. $\mathrm{A}_{1}$ : Kidney of Control Rat ; $\mathrm{B}_{1}:$ Kidney of Rat Tested with $3.5 \mathrm{Mg} / \mathrm{Kg} \mathrm{B}$. W. ; $\mathrm{C}_{1}$ : Kidney of Rat Tested with $35 \mathrm{Mg} / \mathrm{Kg} \mathrm{B}$. W. ; D $\mathrm{D}_{1}$ : Kidney of Rat Tested with $350 \mathrm{Mg} / \mathrm{Kg} \mathrm{B}$. W. A 2 : Heart of Control Rat ; B : Heart of Rat Tested with $3.5 \mathrm{Mg} / \mathrm{Kg} \mathrm{B}$. W. ; $\mathrm{C}_{2}$ : Heart of Rat Tested with $35 \mathrm{Mg} / \mathrm{Kg} \mathrm{B}$. W. ; $\mathrm{D}_{2}$ : Heart of Rat Tested with $350 \mathrm{Mg} / \mathrm{Kg}$ B. W. 


\subsection{Effects of ETASg on the histology of the liver, kidneys and heart of Wistar rats}

Histological sections revealed normal liver sections of rats treated with distilled water (Fig. 3 A). Hepatocytes form flattened laminae with large, clearly visible nuclei. Also, no hepatic lesion was observed on the hepatic architecture of the rats tested with $3.5 \mathrm{mg} / \mathrm{kg} \mathrm{b}$. w. of ETASg (Fig. 3 B). On the other hand, micro-vesicular steatosis is noted in the rats tested with 35 and $350 \mathrm{mg} / \mathrm{kg} \mathrm{b}$. w. of ETASg with dilation of the sinusoid capillaries (Fig. $3 \mathrm{C}$ ). Micro-vesicular steatosis associated with pycnosis are observed not significantly at the dose of $350 \mathrm{mg} / \mathrm{kg} \mathrm{b}$. w (Fig. $3 \mathrm{D}$ ). After the administration was stopped, the anomalies observed disappeared at the end of the 120 days (Table 2).
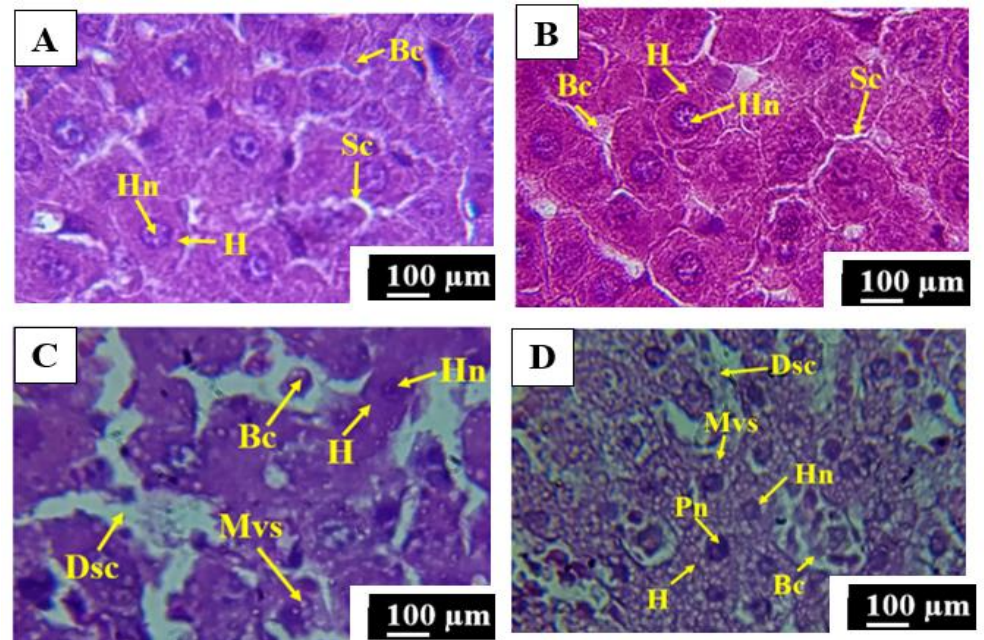

Fig. 3: Photomicrographs Showing Sections of Liver Tissue in Rats Tested for 90 Days. A : Group A (Rat Tested with Distilled Water) ; B : Group B (Rat Tested with $3.5 \mathrm{Mg} / \mathrm{Kg} \mathrm{B}$. W.) ; C : Group C (Rat Tested with $35 \mathrm{Mg} / \mathrm{Kg} \mathrm{B}$. W.) ; D : Group D (Rat Tested with $350 \mathrm{Mg} / \mathrm{Kg}$ B. W.) ; (Magnification X 1000) ; Hematoxylin-Eosin Staining ; H : Hepatocyte ; Hn : Hepatocyte Nucleus ; Sc : Sinusoid Capillary ; Dsc : Dilated Sinusoid Capillary ; Bc : Blood Cells ; Mvs : Micro-Vesicular Steatosis ; Pn : Pycnotic Nucleus.

Table 2: Lesions Induced by ETASg on the Liver of Wistar Rats

\begin{tabular}{|c|c|c|c|c|c|c|}
\hline Duration of experiment & Groups & $\begin{array}{l}\text { Normals } \\
\text { livers }\end{array}$ & Steatosis & Pycnosis & $\begin{array}{l}\text { Steatosis } \\
\text { with Pycnosis }\end{array}$ & Dilated sinusoid capillary \\
\hline \multirow{4}{*}{ At the end of the 90 days } & A (Distilled water) & $100 \%$ & $0 \%$ & $0 \%$ & $0 \%$ & $0 \%$ \\
\hline & B (3.5 mg/kg b. w.) & $100 \%$ & $0 \%$ & $0 \%$ & $0 \%$ & $0 \%$ \\
\hline & C (35 mg/kg b. w.) & $65 \% *$ & $25 \%$ & $0 \%$ & $0 \%$ & $10 \%$ \\
\hline & D (350 mg/kg b. w.) & $50 \% * *$ & $40 \%$ & $0 \%$ & $5 \%$ & $5 \%$ \\
\hline \multirow{2}{*}{$\begin{array}{l}\text { At the end of the } 120 \text { days } \\
\text { (Reversibility) }\end{array}$} & E (Distilled water) & $100 \%$ & $0 \%$ & $0 \%$ & $0 \%$ & $0 \%$ \\
\hline & F (350 mg/kg b. w.) & $100 \%$ & $0 \%$ & $0 \%$ & $0 \%$ & $0 \%$ \\
\hline
\end{tabular}

A : Group of rats tested with distilled water ; B : Group of rats tested with $3.5 \mathrm{mg} / \mathrm{kg} \mathrm{b}$. w. of ETASg ; C : Group of rats tested with $35 \mathrm{mg} / \mathrm{kg}$ b. w. of ETASg ; D : Group of rats tested with $350 \mathrm{mg} / \mathrm{kg} \mathrm{b}$. w. of ETASg ; E : group of rats tested with distilled water ; F : group of rats tested with $350 \mathrm{mg} / \mathrm{kg}$ b. w. of ETASg; $\mathrm{n}=20$ rats ; $* \mathrm{p}<0.05 ; * *=\mathrm{p}<0.01:$ significant difference.

The sections of rats tested with distilled water showed histologically intact and normal kidneys. The glomerular capsule, glomerular space, proximal bypassed tube and distal by passed tube were clearly visible and distinct (Fig. 4 A). The administration of ETASg did not cause any damage to the renal tissues of the rats tested with $3.5,35$ and $350 \mathrm{mg} / \mathrm{kg} \mathrm{b}$. w. compared to the renal tissues of control rats (Figs. $4 \mathrm{~B}$, $\mathrm{C}$ and D).
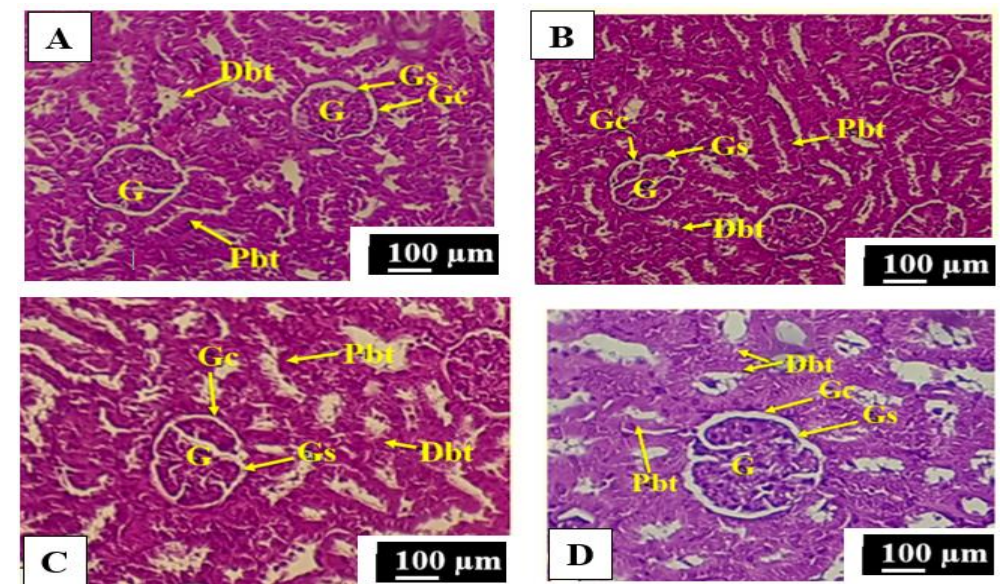

Fig. 4: Photomicrographs of Rats Kidneys Tested for 90 Days Showing Normal Appearance Renal in the Cortex. A : Batch A (Rat Tested with Distilled Water) ; B : Batch B (Rat Tested with $3.5 \mathrm{Mg} / \mathrm{Kg} \mathrm{B}$. W.) ; C : Batch C (Rat Tested with $35 \mathrm{Mg} / \mathrm{Kg} \mathrm{B}$. W.) ; D : Batch D (Rat Tested with $350 \mathrm{Mg} / \mathrm{Kg} \mathrm{B}$. W.) ; (Magnification X 1000) ; Hematoxylin-Eosin Staining; G : Glomerulus ; Gc : Glomerular Capsule ; Gs : Glomerular Space; Pbt : Proximal Bypassed Tube; Dbt : Distal Bypassed Tube. 
The heart of rats tested with distilled water presented a normal anatomical structure (Fig. 5 A). The cardiac muscle fibers are well delimited by myocardial cavities. The oral administration of ETASg did not induce any damage to the cardiac tissues of rats tested with $3.5,35$ and $350 \mathrm{mg} / \mathrm{kg} \mathrm{b}$. w. compared to cardiac tissues of the control rats (Figs. $5 \mathrm{~B}, \mathrm{C}$ and D).
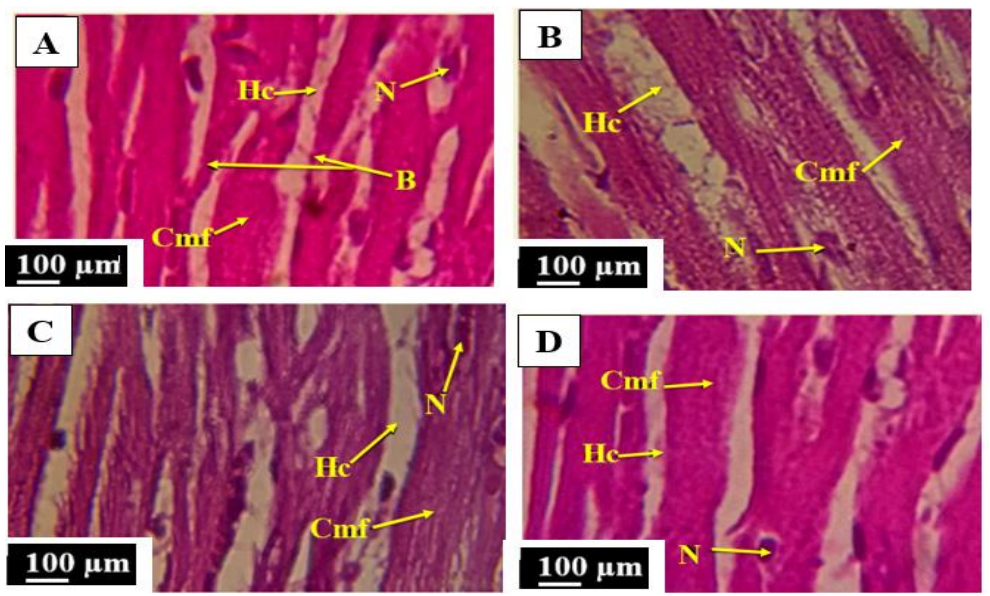

Fig. 5: Photomicrographs of Rats Heart Tested for 90 Days Showing the Normal Appearance. A : Group A (Rat Tested with Distilled Water) ; B : Group B (Rat Tested At 3.5 Mg/Kg B. W.) ; C : Group C (Rat Tested at $35 \mathrm{Mg} / \mathrm{Kg} \mathrm{B}$. W.) ; D : Group D (Rat Tested at $350 \mathrm{Mg} / \mathrm{Kg} \mathrm{B}$. W.) ; (Magnification X 1000); Hematoxylin-Eosin Staining ; Cmf : Cardiac Muscle Fibers ; Hc : Heart Cavity ; N : Nucleus ; B : Bifurcations.

\section{Discussion}

Macroscopic examination of rats tested with the therapeutic dose of $3.5 \mathrm{mg} / \mathrm{kg}$ b. w. of ETASg showed normal liver. No structural anomaly with the naked eye was detected in the liver. Likewise, the relative liver body weight and hepatic histological architecture of these rats not showed significant changes compared to that of the control rats. On the other hand, rats' treatement with $35 \mathrm{and} 350 \mathrm{mg} / \mathrm{kg} \mathrm{b}$. w. of ETASg caused dose-dependent changes in color and appearance resulting in the presence of whitish nodules. In addition, the hepatic histological architecture had shown the presence of micro-vesicular steatosis with dilation of sinusoid capillaries and pycnosis at the dose of $350 \mathrm{mg} / \mathrm{kg}$ b. w. Moreover, no significant variation in the mean relative liver body weight was observed in the rats tested with $35 \mathrm{and} 350 \mathrm{mg} / \mathrm{kg} \mathrm{b}$. w of ETASg compared to those of the control group. The change of color and appearance observed would be due to denaturation of the parenchymal structures (Martin and Feldmann, 1983). The presence of whitish nodules is explained by an inflammatory hepatic reaction. Microscopically, these nodules are characterized in the form of micro-vesicular steatosis. This form of steatosis is characterized by the presence of several lipid vacuoles in a hepatocyte without displacement of its nucleus. It would be caused either by the toxicity of ETASg at high dose, or by a defect in the oxidation of fatty acids (Nassir et al., 2015). Indeed, some authors reported that during drug intoxication, there was a first inhibition of $\beta$-oxidation which leads to an accumulation of fatty acids in the cytosol in the form of emulsified triglycerides (Fromenty and Pessayre, 1995). It caused typically micro-vesicular steatosis without displacement of the nucleus at the center of the hepatic cell. The pycnoses observed in the hepatocytes of rats at $350 \mathrm{mg} / \mathrm{kg} \mathrm{b}$. w. assumed that over a long period of use, ETASg would cause necrosis of liver cell because pycnosis is reversible lesion which occurs before cell necrosis (Chandrasoma and Taylor, 1997). The dilation of the sinusoids observed in our work showed that there was a destruction of the sinusoidal wall due to a dissociation of peri-sinusoidal matrix thus atrophying the nearby hepatocyte spans (Scoazec, 1999). Otherwise, the reversibility study of the observed effects showed that the macroscopic and microscopic liver abnormalities disappeared after 30 days of stopping the administration of ETASg at $350 \mathrm{mg} / \mathrm{kg} \mathrm{b}$. w. This result attested to that of the study of reversibility observed during biochimical analysis. In this study, the increase of ALAT due to ETASg at the dose of $350 \mathrm{mg} / \mathrm{kg} \mathrm{b}$. w. was moderate and reversible (Otis et al., 2018). These results suggest that ETASg would not disrupt liver structure and retain the architecture of liver tissue when administered with the therapeutic dose of $3.5 \mathrm{mg} / \mathrm{kg} \mathrm{b}$. w. orally for $90 \mathrm{days}$. However, ETASg at doses of 35 and $350 \mathrm{mg} / \mathrm{kg} \mathrm{b}$. w., would alter the appearance and liver tissue integrity of the rats tested during 90 days administration period. Our results disagree with study by Debelo et al. (2916). They showed that the aqueous extrat of the leaves of Thymus schimperi (Lamiaceae) did not influence the appearance and tissue structure of liver of rats treated with $200 \mathrm{and} 600 \mathrm{mg} / \mathrm{kg} \mathrm{b}$. w for 90 days of experimentation. But, similar results were observed by some researchers (Kognou et al., 2018) with administration of the ethanolic stem bark extract of Dichaetanthera africana (Hook. F.) Jacq. Fel. (Melastomataceae) caused liver damage such as vascular congestion and hepatocyte inflammation sites in rats treated with 500 and $1000 \mathrm{mg} / \mathrm{kg} \mathrm{b}$. w. for 90 days.

Concerning the anatomo-histological study of kidneys, macroscopic examination showed no change in the color and appearance of the kidneys of the rats tested at all the doses studied of ETASg compared to those of the control rats. In addition, the relative body weight of the kidneys did not show any significant variation $(\mathrm{p}>0.05)$ compared to that of the control rats. The microscopic examination revealed no significant damage to the kidney tissue. Indeed, the glomerulus was clearly observable on the histological sections. It presented a closed glomerular capsule well delimited by a glomerular space. The proximal bypassed tube and the distal bypassed tube were clearly recognizable. These results obtained, would explain an absence of modification of the renal structure of the rats having received ETASg at the doses tested. Our results corroborate those obtained by (Nene-Bi et al., 2016). Indeed, these authors showed during a subchronic study that the oral administration of the aqueous stem bark extract of Bridelia ferruginea (Euphorbiaceae) did not influence the renal tissue of rats tested with $400 \mathrm{mg} / \mathrm{kg} \mathrm{b}$. w.

In contrast, effect of ETASg on the histology of the kidneys of rats tested in our study is different from the results of the studies conducted by (Legbosi and Ellis, 2018). Indeed, these have shown that the renal architecture of rats tested with the hydromethanolic stem bark extract of Musanga cecropioides (Urticaceae) at doses of 125,250 and $500 \mathrm{mg} / \mathrm{kg} \mathrm{b}$. w. presented fibrosis and tubular necrosis.

Macroscopic histology of the heart showed, no perceptible abnormality at all doses studied compared to that of the control rats. In addition, no significant change in the relative body weight of the rat's heart was seen at all doses compared to controls. Histological sections of the heart of rats tested at all doses of ETASg showed normal heart cells. The myocardial fibers observed have kept their normal anatomical structure. Therefore, ETASg would not influence the structure of the hearts of rats at all doses studied. This result suggests that this extract, administered orally to rats for 90 days, does not have a toxic effect on the heart. The effects of ETASg on the histology of heart of the rats 
tested in our study were similar to the results of studies by Udeh et al. (2018). These authors showed that the histological test of the heart of the rats tested with the methanolic extract of the leaves of Gnetum africanum Welw (Gnetaceae) at the doses of 10, $20 \mathrm{and} 40 \mathrm{mg} / \mathrm{kg} \mathrm{b}$. w. has normal heart tissue after 90 days of experimentation.

\section{Conclusion}

The anatomo-histological study has shown that the oral administration of ETASg retained the tissue integrity of the liver of rats having received the therapeutic dose of $3.5 \mathrm{mg} / \mathrm{kg} \mathrm{b}$. w. However, ETASg induces hepatic abnormalities at the macroscopic and microscopic level in the rats tested at the doses of 35 and $350 \mathrm{mg} / \mathrm{kg} \mathrm{b}$. w. Furthermore, ETASg is well tolerated by the kidney and heart tissue at all doses tested for 90 days of experimentation. In total, ETASg is not toxic one hand for the liver of rats at $3.5 \mathrm{mg} / \mathrm{kg} \mathrm{b}$. w., and on the other hand, for the kidneys and the heart at all the doses studied. It would be wise to supplement this study with chronic toxicity tests, to confirm its non-toxic nature.

\section{References}

[1] Aubréville A (1959). The forest flora of Côte d'Ivoire. 2nd revised edition, Volume 3, Publication No 15 of the Tropical Forestry Center, France, pp 66-70.

[2] Chandrasoma P, Taylor CR (1997). Concise pathology. $3^{\text {rd }}$ Edition, McGraw-Hill Singapore, $317 \mathrm{p}$.

[3] Debelo N, Afework M, Debella A, Makonnen E, Ergete W, Geleta B (2016). Assessment of hematological, biochemical and histopathological effects of acute and sub-chronic administration of the aqueous leaves extract of Thymus schimperi in rats. Journal of Clinical Toxicology 6(2) : 1-9 https://doi.org/10.4172/2161-0495.1000286.

[4] Fennell CW, Lindsey KL, McGaw LJ, Sprag SG, Stafford GI, Elgoraschi EE, Grace OM, Van Staden J (2004). Assessing African medicinal plants for efficacy and safety: pharmacological screening and toxicology. Journal of Ethnopharmacology 94 : 205-217 https://doi.org/10.1016/j.jep.2004.05.012.

[5] Fromenty B, Pessayre D (1995). Inhibition of mitochondrial bêta-oxidation as a mechanism of hepatotoxicity. Pharmacology Thermal (67) : 101154 https://doi.org/10.1016/0163-7258(95)00012-6.

[6] Hould R (1984). Histopathology and cytopathology technique, Edition Maloine, Paris-France, 399 p.

[7] Kognou MLA, Tchamgoue DA, Tchokouaha YRL., Nthenge-Ngumbau ND, Fokou TVP, Tchinda TA, Agbor AG, Etame EMR, Mouokeu SR, Gueiffier EC, Pawar SR, Mouelle SA, Ngane NAR (2018). Acute and sub-chronic toxicity studies of Dichaetanthera africana (Hook. F.) Jacq. Fel. (Melastomataceae) stem bark ethanol extract. Journal of Applied Pharmaceutical Science 8(6): 147-155 https://doi.org/10.7324/JAPS.2018.8619.

[8] Koné M, Bléyéré NM, Yapo AP, Vangah MO, Ehile EE (2009). Evaluation of the toxicity of an aqueous extract of Sacoglottis gabonensis (Baille) Urban (Humiriaceae) in rodents, a plant used in the treatment of Buruli ulcer in Côte d'Ivoire. International Journal of Biology Chemical Science 3(6) : 1286-1296 https://doi.org/10.4314/ijbcs.v3i6.53147.

[9] Koné M, Vangah-Manda OM, Kouakou H, Yapo AP, Bléyéré NM, Datté YJ (2007). Influence of Sacoglottis gabonensis (Baille) Urban and Okoubaka aubrevillei Normand and Pellegrin on the in vitro growth of Mycobacterium ulcerans. Medicine Black Africa 54(11) : 549-554.

[10] Kouassi KB, Adjambri AE, Koné M, Sawadogo D, Yapo AP (2018). Influence of an aqueous extract of Sacoglottis gabonensis (Baille) Urban (Humiriaceae) stem bark, a plant used in the traditionnal treatment of Buruli ulcer, on anthropometric and hematological parameters in wistar rat. The Pharma Innovation Journal 7(3) : 104-110

[11] Legbosi LN, Ellis RT (2018). Sub-chronic toxicity of hydromethanolic stem bark extract of Musanga cecropioides (Urticaceae) in rat. EC Pharmacology and Toxicology 6(3): 76-95.

[12] Martin E, Feldmann G (1983). Histopathology of the liver and bile ducts in adults and children, Edition Masson, France, $357 \mathrm{p}$.

[13] Martoja R, Martoja-Pierson M (1967). Introduction to the techniques of histology. Edition Masson et Cie, Paris, France, 345p.

[14] Nassir F, Rector SR, Hammoud GM, Jbdah JA (2015). Pathogenesis and Prevention of Hepatic Steatosis. Gastroenterrology and Hepatology 11(3): 167-175. PMID: 27099587; PMCID: PMC4836586.

[15] Nene-Bi SA, Ramachandran V, Rao PV, Krishnan RRG, Dhanabal SP, Traore F (2016). Subchronic toxicity studies of the aqueous stem bark extract of Bridelia ferruginea in Wistar rats. Bulletin of Environment. Pharmacology and Life Sciences 5(10): 14-21.

[16] Nortier J, Depierreux M, Vanherweghem JL (1999). Phytotherapy and nephrotoxicity. Journal of Medicine Brussels 1 : 9-14.

[17] OECD (1998). OECD Guideline for the Testing of Chemicals: Repeated-dose oral toxicity to rodents, 90 days. OECD $408,16 \mathrm{p}$.

[18] Otis TBI, Kouassi KB, Gnangoran BN, Kone M, Yapo AP (2018). Subchronic Toxicity Study of the Extract of Sacoglottis gabonensis (Baille) Urban (Humiriaceae) in Wistar Rats. International Journal of Biochemistry Research \& Review 24(1) : 1-10 https://doi.org/10.9734/IJBCRR/2018/44353.

[19] Peyrin-Biroulet L, Barraud H, Petit-Laurent F, Ancel D, Watelet J, Chone L, Hudziak H, Bigard MA, Brenowicki JP (2004). Hepatotoxicity of herbal medicine: clinical, biological data, histological and mechanisms involved for some typical examples. Clinical and Biological Gastroenterology 28(7): 540-550 https://doi.org/10.1016/S0399-8320(04)95009-9.

[20] Rocquelin G (1979). Pathology research in rats ingesting different doses of peanut oil or rapeseed oil with low erucic acid content (Huile de colza Primor): Animal growth and organ weights. Annals of animal biology, biochemistry, biophysics, pp 483-485. https://doi.org/10.1051/rnd:19790403.

[21] Scoazec JY (1999). Hepatic endothelial cells: an unexpected diversity and its physiological and pathophysiological consequences. Hepato-gastrology and digestive oncology 6(3): 209-220.

[22] Udeh EN, Anaga A, Asuzu UI (2018). Acute and sub-chronic oral toxicity studies on methanol leaf extract of Gnetum africanum Welw in Wistar rats. American Journal of Research in Medical Sciences 3(1): 7-14. https://doi.org/10.5455/ajrms.20180109094114.

[23] Vangah OM, Kroa E, Zai LP (2000). Census of traditional health practitioners, practices, pathologies and medicinal plants of Côte d'Ivoire. TV: Lakes Region: Toumodi Department, Yamoussoukro, Tiébissou and Didiévi Sub-Prefecture. WHO-CI Technical Report, 40 p.

[24] World Health Organization (WHO) (2008). Traditional medicine. Fact sheet $\mathrm{N}^{\circ} 134$. WHO/EDM/TRM, Genève-Suisse, 79 p. 